ECONOMICS \& STATISTICS DISCUSSION PAPER

No. 068/12

\title{
The Italian banking system: Facts and interpretations
}

\author{
Riccardo De Bonis
}

Alberto Franco Pozzolo

Massimiliano Stacchini 


\title{
The Italian banking system: Facts and interpretations
}

\author{
Riccardo De Bonis,* Alberto Pozzolo,** and Massimiliano Stacchini*
}

\begin{abstract}
The paper compares the essential features of the Italian banking system with those of the other large euro-area countries. The analysis focuses on banks' size, ownership and competitiveness, their role in financing firms, the composition of their balance sheets and their degree of internationalization, profitability and terms for customers. Within this overall framework the paper examines the banking system's response to the financial crisis of 2007-09 and subsequent developments. The progress made in decades past is recalled and further necessary steps set out.
\end{abstract}

*Banca d'Italia, Economic Research and International Relations area, Economic and Financial Statistics Department. **University of Molise, CASMEF and MOFIR. The authors thank Massimiliano Affinito and Matteo Piazza for comments on a previous version of this paper. Unless otherwise stated, the paper uses data available as at 20 September 2011. The paper has been published in the special issue of the Review of economic conditions in Italy on "Banking system and economic development in China and Italy", published in 2012. The opinions are those of the authors alone and do not involve the responsibility of the Bank of Italy or the Eurosystem. 


\section{Introduction}

Banks have always been the main source of finance for the Italian economy, so grasping the main features, strengths and weaknesses of the banking system is essential to understanding the country's economic prospects, especially given the growing integration of international financial markets. This paper discusses the main facts concerning Italy's banking system, comparing it with those of the other large euro-area countries, Germany, France and Spain. After gauging the system's size (Section 1) and role in the financing of firms (Section 2), the essay analyzes its structure and geographical distribution (Section 3) and ownership (Section 4). We next focus on the composition of banks' balance sheets (Section 5), degree of internationalization (Section 6), profitability (Section 7) and the cost of loans (Section 8). This is followed by an account of the Italian credit system's reaction to the financial crisis of 2007-09 and developments thereafter (Section 9). The conclusions sum up the indubitable progress made in years past and detail the ground that Italy still needs to make up.

\section{A small banking system within a small financial system}

The Italian banking system is small. At the end of 2010 total balance-sheet assets came to 2.5 times the country's GDP, compared with 3.3 times in Germany and Spain and 4.1 times in France (Table 1). Most of the other main indicators of banking business, such as deposits or lending to households in relation to GDP point to similar conclusions.

Economic theory offers no consensus explanation of the determinants of the size of the banking and financial system. But even without a theoretical frame of reference we can argue that it is influenced by a country's historical legacy, by the legal and regulatory system (La Porta et al., 
1997; Demirgüç-Kunt and Levine, 2001), by tax systems, by social capital (Guiso et al., 2004), and by the political and institutional system (Rajan and Zingales, 2003). ${ }^{1}$

With due caution, it can be maintained that the Italian banking system is small because the entire financial system is less highly developed than in other countries. And in fact the portion of total financial assets consisting of bank assets in Italy is comparable to that in the other countries of Europe (Table 1). In proportion to GDP, however, stock market capitalization is lower (28 per cent at the end of 2010 in Italy as against 42 per cent in Germany, 44 per cent in Spain and 67 per cent in France). And the relative size of the financial sector - banks, the central bank, non-bank intermediaries, insurance companies and private-sector pension funds - is also smaller, owing above all to the lesser development of insurance companies and pension funds.

On the liability side, the lower ratio of bank deposits to GDP could depend on the larger portion of household portfolios that consists of debt securities of government and private corporations, whose liquidity is comparable to that of time deposits, and on the competition of post office deposits, which is not as strong abroad as in Italy because post offices have often been privatized and converted into banks.

\section{The banks are central to the financing of firms}

In this small financial system, the importance of banks in providing finance to firms stands out. Italy's underdeveloped stock market and underdeveloped corporate bond market have always made industry dependent on bank credit. Fewer than 300 companies are listed on the stock exchange, compared with 760 in Germany and 630 in France. Italy remains a country of small firms, which average just 3 workers each, against 4 in Spain, 6 in France and 11 in Germany. Company owners

\footnotetext{
${ }^{1}$ On banks and financial markets in the developed countries see among others Levine and Zervos (1998), Allen and Gale (2000), and De Bonis and Pozzolo (2012).
} 
make limited contributions of capital. Italy has one of the lowest ratios of own funds to total company liabilities, and debt financing is correspondingly important. ${ }^{2}$

The major role of banks for the Italian economy was apparent already at the end of the nineteenth century. The classical interpretation is that France, Germany and Italy were not ready to rely on the financial markets to fund economic growth because of competition from the United Kingdom, the dominant power of the day, which had built up a significant competitive advantage in the financial sector. In France, Germany and Italy the financing of industrial growth had to take paths different from the British, combining a major role for the banks with that of the state (Gerschenkron, 1962). Apart from this historical heritage, the underdevelopment of the financial markets in Italy has also been ascribed to other factors: the determination of mainly familycontrolled firms to keep outside shareholders away; the prevalence of the public pension system, which leaves little room for institutional investors and thus reduces the potential demand for shares; and the legal system, which has been blamed for failing to protect minority shareholders and small investors (for a recent review and summary, see Enriques et al., 2011).

Whatever the explanation for the relative backwardness of Italian financial markets, there is no doubt that it has helped to make bank funding central. Bank lending to firms is equal to 57 per cent of GDP, compared with 43 per cent in France and 36 per cent in Germany; only Spain, another bank-based financial system, has a higher ratio, 86 per cent. Bank credit to sole proprietorships is also higher in Italy than in the rest of the euro area.

Italian banks' marked specialization in lending to small businesses has also influenced the overall evolution of the system (Cetorelli and Strahan, 2006). Very often relations between banks and firms are on a fiduciary basis that is a serious impediment to the expansion of credit institutions (Alessandrini et al., 2009).

\footnotetext{
${ }^{2}$ See Carosio (2011) and Mirra and Pozzolo (2011).
} 


\section{The structure of the system: large groups and small banks, little market concentration}

The Italian banking system at the turn of the 1990s has been described as a "petrified forest" whose essential features were unchanged since the 1930s. By international standards there were a large number of banks and a small number of branches; the system was dominated by local oligopolies. It was hard for any bank to penetrate where its competitors were traditionally established. Branch openings were regulated and rationed, and bank mergers were not encouraged or were prohibited outright, given the massive presence of state-owned banks (see Section 4).

Since 1990, the structure of the banking system has changed owing to two chief factors: the liberalization of branching and the increase in mergers and acquisitions. The number of branches jumped from 16,600 in 1990 to 33,600 in 2010: more new branches were established in these twenty years than in the previous sixty, when barriers to moving into local markets were in place. And between 1990 and 2006, mergers and acquisitions redistributed market shares amounting to a third of total banking assets. This wave of consolidations was the main factor in reducing the number of banks from 1,200 in 1990 to under 800 today. Even so, the average number of banks per province has risen. The liberalization of branch openings led to greater territorial overlap between banks, to the benefit of competition. ${ }^{3}$

Despite the mergers and acquisitions, Italy still has a comparatively high number of banks: less than half as many as in Germany but slightly greater than in France's larger banking market and more than twice as many as in Spain (Figure 1). The large number of banks means relatively low asset concentration, higher only than Germany's in the euro area. The Herfindahl index for Italian bank assets is less than 400 , and the five largest intermediaries hold just over one third of all bank assets (Table 2). The greatest concentration among the main countries is in France, with a Herfindahl index of over 600 and five banks holding nearly half of all assets. The low degree of

\footnotetext{
${ }^{3}$ See among others De Bonis and Ferrando (2000), Angelini and Cetorelli (2003) and the essays brought together in Messori et al. (2003), Panetta (2004) and Silipo (2009).
} 
concentration in Italy also reflects the fact that in the case of the larger banks acquisitions have outweighed mergers. Italian banking concentration would be greater if it were measured by consolidated statistics for banking groups.

Economic analysis is critical of the use of the national concentration index, since for retail banking the relevant market is provincial or at most regional. Local banking market concentration in Italy is low, while in Germany it is very high (European Commission, 2006). Examining the role of local banks in the European Structural Funds' Objective 1 regions of Italy, Spain and Germany from 2000 to 2006, Nuzzo and Oliviero (2011) come to a similar conclusion. The presence of local banks in these areas is less substantial in Italy than in Germany or Spain, confirming the diminished importance of provincial or regional oligopolies.

Italian banks tend to be relatively small, whether in terms of assets or number of employees. On average, they are larger than German but smaller than French or Spanish banks. However, the large number of branches, with relatively small staffs, results in a territorial presence on a par with that of the other countries save Spain, where the dispersion of the population has favoured the creation of an extremely extensive branch network (Figure 2). Today the number of inhabitants per branch is 1,794 in Italy, much higher than in Spain $(1,034)$, comparable with France $(1,676)$, and lower than in Germany $(2,077)$.

The smaller size of the banking system translates into a relatively smaller number of bank employees: 1.4 per cent of the total work force, compared with 1.8 per cent in France and 1.7 per cent in Germany (Table 2). Even so, the value of assets under management per employee is the lowest of all the main euro-area countries. 


\section{Ownership is private}

From a long-run perspective, the transition to private ownership in the 1990s was probably the single most important change to the Italian credit system since the Second World War. As a result of government rescue operations during the Great Depression, by the end of the 1930s state-owned banks held 70 per cent of total credit system assets, a market share that remained broadly unchanged for six decades. In the 1990s, after the transformation of the public banks into limited companies, privatization got off to a fast start. Italy has ended public ownership of banks, de facto, unlike Germany and Spain, where government holdings of bank capital remain a distinctive trait of the national economy, or such other countries as the United Kingdom and Ireland, where the financial instability triggered by the crisis of 2007 led to the practical nationalization of a good part of the credit system. ${ }^{4}$

Italian banks are either limited companies, cooperative banks (banche popolari), or mutual banks (banche di credito cooperativo). At the end of 2010 the market shares of these three categories were respectively 80 per cent, 9 per cent, and 7 per cent of customer deposits, with branches of foreign banks holding the remaining 5 per cent.

The characteristics of the banking system include concentrated ownership, cross shareholdings and interlocking directorates. The concentration of ownership, which is a common trait of Italian listed companies in general, is less pronounced among banks than among companies in other industries. Cross shareholdings among the large banks are less extensive than in the other countries of continental Europe (Gobbi, 2008). In theory, interlocking directorates, another feature shared by industrial firms, could distort competition, especially when the same men sit on the boards of banks and borrower firms (Autorità garante della concorrenza and del mercato, 2010). On the other hand, the presence of bankers on corporate boards may also have served to certify their creditworthiness

\footnotetext{
${ }^{4}$ On the bank bail-outs of 2008-09, see Panetta (2010).
} 
vis-à-vis lenders not present on those boards, thus attenuating informational asymmetry and helping to contain interest rates (Stacchini and Cau, 2010).

The financial crisis confirmed that good corporate governance is essential to banks' stability (Mehran et al., 2011). In Italy, the discussion now centres on three main themes. One, in the spotlight for decades now, is the reform of the banche popolari. As in other countries, they are characterized by limits on the size of individual shareholdings, equal voting rights (one member, one vote), and clauses requiring approval of new members. These are features that Italy's banche popolari share with the German Volksbanken and the French banques populaires. ${ }^{5}$

These governance arrangements would still seem to be appropriate to the small banche popolari, whose customers largely coincide with their membership. But the largest banche popolari, which now do business outside their original home areas and are listed on the stock exchange, more closely resemble public limited companies in which directors are relatively sheltered from takeover risk. Although historically the cooperatives have equaled or topped the profit performance of the credit system as a whole, ${ }^{6}$ several pieces of legislation have been drafted to improve their governance, especially that of the listed banche popolari. The proposals are to raise the ceiling on share ownership, increase the role of institutional investors, simplify the procedure for transforming the cooperatives into limited companies, facilitating the transferability of shares, and introducing measures to increase shareholders' participation at membership meetings (Tarantola, 2011).

The second theme is the role of banking foundations. Starting in the 1990s the old public banks transferred their assets and liabilities to new limited share company banks, of which they took control in the form of foundations. The foundations were then recognized as private law persons. Frequently they gave up their controlling stakes. Today they retain stakes larger than 5 per cent in over 50 banks and hold more than 20 per cent in two of Italy's major banks (IMF, 2011). The

\footnotetext{
${ }^{5}$ On the characteristics of cooperative banks in Europe, see Ayadi et al. (2010).

${ }^{6}$ Cau et al. (2004).
} 
foundations have ensured stable ownership arrangements in Italian banks and carried out substantial recapitalizations during the crisis.

The third theme - regardless of the intermediaries' governance and control structure - is the recent intervention of the Bank of Italy as supervisory authority on various aspects of corporate governance, to underscore in particular: i) that the functions of strategic oversight, management and control must be distinct so as to avoid overlapping and conflicts of powers; ii) that the body responsible for strategic oversight must include independent directors as a safeguard in the matters most subject to conflicts of interest; and iii) that executive compensation must be consistent not only with the need to attract talent but also with the bank's long-run objectives. Thanks to these interventions, among other things, the presence of local politicians on the boards of the foundations does not appear to have undercut the banks' independent management. ${ }^{7}$

\section{Balance-sheet composition: lots of retail funding, little interbank funding, low leverage}

The Italian economy's low degree of financialization and the specialization in finance to firms have had pronounced effects on banks' balance sheets. On the asset side, at the end of $2010^{8}$ the relatively large share accounted for by loans to firms corresponded to a lower proportion of home mortgages and consumer lending to households, especially in relation to GDP. There are various explanations of why Italy has lagged behind in lending to households: their credit demand may have been reduced, until very recently, by a high propensity to save, together with the mechanism of intergenerational transfers both of money and of home ownership; there has been a cultural diffidence towards personal debt, and the banks have been prudent in expanding this line of business. It is no coincidence that the branches of foreign banks have gained market shares in

\footnotetext{
${ }^{7}$ The issue is complicated. According to Infante and Piazza (2010), loans to firms whose boards include a politician carry lower interest rates when the bank too has a politician on its board or a foundation as shareholder.

${ }^{8}$ For an analysis covering the first few years of the euro, see Affinito et al. (2006).
} 
lending to households, a field in which these new entrants are less vulnerable to information asymmetry than in lending to businesses (Infante and Rossi, 2009). Households' lower leverage is one of the factors that buffered the impact of the 2007 crisis on Italian banks.

Still on the asset side, securities make up a smaller portion of Italian banks' assets than the average in the euro area (17 as against 19 per cent; Table 3a). But the share of government securities is larger, virtually all in the form of Italian Treasury paper; the exposure to other sovereign debtors is negligible. In July 2011 the ratio of government securities holdings to banks' capital plus reserves was 67 per cent in Italy, roughly equal to the euro-area average and sharply lower than the 81 per cent registered in Germany. By contrast, interbank exposures are very low, especially by comparison with Germany and France, owing notably to the absence of the large bilateral interbank exposures that are found in the rest of Europe. ${ }^{9}$

Symmetrically, the liability side reveals the importance of retail business in Italy. At the end of 2010 customer deposits accounted for 37 per cent of total liabilities in Italy, compared with 32 per cent in the euro area as a whole (Table 3b). The portion of total deposits consisting of current accounts is the highest in the area, while time deposits make up a relatively small share. The portion consisting of bonds has increased greatly in recent years (to 21 per cent of total liabilities in Italy against 15 per cent in the euro area). Since the turn of the century the tax treatment of interest income has discouraged time deposits and offered an incentive for bond issues. ${ }^{10}$ The banks increased their bond issuance in part in order to expand their medium- and long-term lending, which nevertheless remains less important than in other countries. Their market power certainly facilitated the placement of bonds, which the public perceives as safe (no Italian bank in memory has ever defaulted on its securities issues). The portion of liabilities accounted for by interbank loans is lower than in the rest of the euro area. Italian banks' lesser reliance on wholesale funding helped

\footnotetext{
${ }^{9}$ On recent developments in interbank business see Cappelletti et al. (2011).

${ }^{10}$ The Italian Government's public finance package during the summer of 2011 provides for equalizing the tax rate on income on bank deposits and on bank bonds with a maturity of over 18 months at 20 per cent; the former had been taxed at 27 per cent and the latter at 12.5 per cent.
} 
attenuate the repercussions of the collapse of confidence in the international money market between 2007 and 2009.

Italian banks' capital and reserves in relation to unweighted risk assets - a rough equivalent to the financial leverage indicator called for in the Basel 3 agreements - is high. This gearing ratio is 9 per cent in Italy, compared with 5 per cent in Germany and 6 per cent in the euro area as a whole. This is the result of the relative smallness, as we have seen, of some asset items, in particular trading book securities and interbank loans.

As to capital ratios, Italian banks passed the European Banking Authority's stress test in July 2011 with flying colours. ${ }^{11}$ Considering risk-weighted assets, the solvency ratio of the large Italian banks was lower than the European average, owing to two factors: the absence of the public capital injections by which many European banks have benefited since 2007 and greater supervisory strictness in the definition of eligible capital. ${ }^{12}$ Italian banks have begun the capital strengthening needed to meet the new capital requirements of Basel 3 by 2019 and have raised 50 per cent of the necessary capital.

\section{Internationalization: cross-border business and opening to foreign competition}

Italian banks are less internationalized than those of the other leading industrial countries, both in terms of direct business with non-residents and in terms of the presence of bank branches and subsidiaries abroad. By contrast, the presence of foreign banks in Italy is substantial.

Assets vis-à-vis non-residents accounted for 10 per cent of the total in 2009 (Table 4), compared with 29 per cent in Germany and France and 12 per cent in Spain. This scanty international

\footnotetext{
${ }^{11}$ On the successive requests of new capital due to the increased riskiness of bank assets following the sovereign debt crisis, see the discussion in Section 9.2..

${ }^{12}$ The prudential statistics on bank capital are not harmonized. "As revealed by the crisis, the existing definition of prudential own funds (capital) suffers from several fundamental flaws: (i) lack of a precise boundary between different capital components, (ii) inconsistent definition and application of regulatory adjustments." ECB (2010). See also the European Banking Authority press release of July 2011.
} 
diversification characterizes all the main asset components: loans to non-financial corporations, interbank lending, and securities. On the liability side, non-residents' deposits with Italian banks are in line with German and Spanish banks, lower than those with French banks.

The greater incidence of liabilities than of assets vis-à-vis non-residents reflects the banks' role in financing the net debtor position in international investment that has marked Italy for a good many years now. Whereas in the later 1990s it was chiefly net portfolio investment by non-residents that financed the Italian economy, since then the role of the banks' net debtor position has grown steadily more important (Table 5). The resources raised abroad have funded a growth in lending to residents that has outstripped the banks' domestic fund-raising. And while there is little reliance on interbank funding domestically, in Italy - as in Spain - the interbank market accounts for the bulk of external liabilities, especially within the euro area.

Italian banks' presence abroad with branches or subsidiaries is also limited. Considering banks with total assets of $€ 20$ million or more, Piscitello and Pozzolo (2006) find that they had controlling stakes in 43 foreign banks and had 66 branches abroad. These figures are comparable with those for Spain (47 subsidiaries and 71 branches) but far below those for Germany (109 and 246) or France (140 and 226). This lesser internationalization reflects a general feature of the Italian economy, namely limited outward investment by Italian firms and the country's limited capacity to attract foreign direct investment. As with industrial firms, this is explained in part by the small average size of Italian banks, which has been shown to impede internationalization (see Focarelli and Pozzolo, 2001; Caiazza et al., 2011). In fact, the only two Italian banks comparable in assets and capitalization to leading European intermediaries both display a significant propensity for international business; so much so that they have now been placed under observation by the Basel Committee to assess their systemic importance.

By contrast, the presence and direct operations in Italy of foreign banks are greater than in the other main euro-area countries, with some differences in organizational form. The proportion of 
foreign bank branches is higher than in Germany, lower than in Spain and France. The share of foreign-controlled banks established under domestic law is equal to that in Germany and smaller than in Spain and France (Table 5). Foreign banks doing business in Italy through branches or subsidiaries account for over 13 per cent of total Italian banking system assets, the largest portion in any of the countries considered here. So the Italian banking system must be considered as definitely open to foreign competition.

\section{Banks' profitability is high and relatively stable}

Traditional banking has always constituted a large part of Italian banks' business, and net interest income plays an accordingly large role in the formation of profit (Figure 3). As in the other countries of Europe, since the end of the 1980s the fall in inflation has meant a decline in interest earnings. In Italy, net interest income remains in line with that of Spain, higher than in Germany and France. For Italian banks, income from services is less important than net interest income; it did increase between 1995 and 2000, during the expansion of the financial markets, thanks for instance to fees for the placing of investment fund units (Figure 4). After 2000 revenue from services was curbed by the end of the dot-com bubble but remained high by historical standards. Since 2007, with the financial crisis, it has fallen. Today it is at levels comparable to those found in the other main countries except Germany, where it is lower.

The ratio of Italian banks' operating costs to total assets has come down in the last twenty years but is still higher than in the other countries (Figure 5). The banks are continuing to curb costs. Some have rationalized their branch networks, and in 2009 and 2010, for the first time since branch liberalization in 1990, the number of branches fell.

Italian banks' gross operating profits have traditionally been high. In the last ten years, with the contraction in net interest income, they have diminished but are still higher than in Germany or 
France. Return on equity contracted sharply in the mid-1990s with the crisis at some southern Italian banks (Figure 6), but recovered in 1996 and held at around 10 per cent from 2000 to 2006. The financial crisis drove banks' ROE down everywhere. It remained positive in Italy and Spain but was negative in the UK and Germany in 2008 and 2009 and in France in 2008.

From 1988 through 2009 the average ROE of Italian banks was higher than that of German banks and lower than that of French, Spanish and British (for the latter, however, the high returns were accompanied by high risk, which exploded with the crisis). Additional confirmation of the prudent balance-sheet management of Italian banks come from the fact that the volatility of ROE, whether measured by variation coefficients or standard deviations, has been lower in Italy than elsewhere, except in Spain.

\section{Lending rates in line with euro-area average}

Until the Lehman Brothers default in September 2008, lending rates in the euro area tended to converge. The convergence was greater for home mortgages (Figure 7) and loans to firms (Figure 8), not as marked for consumer credit (Figure 9). But since the end of 2008 the international dispersion of interest rates, measured either by coefficients of variation or by standard deviation, has increased for all types of lending. The financial crisis, the increase in risk and the differing responses of national banking systems inverted the tendency to interest rate convergence. It is worth examining the price of credit charged by Italian banks in comparison with those in other countries in detail. 


\subsection{Loans to firms}

Interest rates on loans to firms in Italy are broadly in line with the euro-area average, both for loans larger than $€ 1$ million, which generally go to larger firms (2.5 per cent in Italy in December 2010, 2.6 per cent in the euro area; Figure 10) and for smaller loans (3.2 per cent in Italy, 3.6 per cent in the area; Figure 11). The lower interest rate charged to large firms reflects a number of factors both in Italy and throughout the area: the banks specializing in large loans enjoy economies of scale in assessing creditworthiness, and in lending to these large corporations, which ordinarily have substantial tangible assets, there is less informational asymmetry, and banks have less market power and take less risk.

One specific feature in Italy is the large role of credit made available through current account overdrafts. In December 2010 Italy accounted for 32 per cent of all euro-area overdraft credit to firms and households, compared with 15 per cent of bank loans. Overdrafts allow the bank to change the interest rate at any time; it is likely that they are utilized by banks as a tool for monitoring small firms' cash flow. For borrowers, this instrument allows the utilization, at their discretion, of any desired portion of the overdraft granted, paying interest only on the amount actually drawn. For firms the cost of current account overdraft credit in Italy is in line with the rest of Europe. For households, the ample supply of overdraft facilities results in lower interest rates.

\subsection{Home mortgage loans}

Since 2003 home mortgage rates in Italy have mostly been lower than the euro-area average (Figure 12). ${ }^{13}$ The only exception came during the three years from 2006 through 2008. During that phase, when the ECB was raising its policy rates, Italian households guarded against the risk of

\footnotetext{
${ }^{13}$ The harmonized statistics on banks' lending and deposit rates for households and firms are available starting January 2003.
} 
further rises (which did materialize) by turning to fixed-rate mortgages, which were more costly in Italy. A typically Italian characteristic, due perhaps to the banks' greater difficulty in raising medium- and long-term funds, is the higher rates on fixed than variable rates, even at times of monetary restriction. Since the end of 2008, at a time of expansionary monetary policy following the Lehman Brothers collapse and the explosion of the financial crisis, Italian mortgage rates have been below the area-wide average. One factor is the great popularity of lower-cost variable-rate mortgages. $^{14}$

\subsection{Consumer credit}

The cost that Italian households sustain to finance consumption is higher than in Germany, France, Spain or the euro area generally (Figure 13). The interest rates on consumer credit are relatively insensitive to monetary policy impulses owing to the structure of its supply and the nature of the demand for this financing service. The supply of consumer credit is marked by the smallness of the market, which impedes returns to scale, and concentration at just a few intermediaries, frequently foreign-controlled, which tends to foster strategies based on market power to set prices higher than marginal costs. $^{15}$

\footnotetext{
${ }^{14}$ On the factors determining the choice between variable and fixed rates, see Paiella and Pozzolo (2007).

15 According to Piazza and Stacchini (2007), the cost of consumer credit in Italy depends chiefly on the degree of competition in this business, not on the risk taken by the banks, especially those at the high end of the interest-rate distribution.
} 


\section{Since 2007: A good response to the crisis and the recent tensions}

\subsection{The financial crisis of 2007-09}

The financial crisis that was triggered in the summer of 2007 by the collapse of the subprime mortgage market in the United States and then spread worldwide had a limited impact on the Italian banking system. The virtues of a more traditional business model based on careful assessment of borrowers' creditworthiness, stable funding and strict supervision ensured that no Italian bank failed and that government injections of capital to banks were extremely modest.

The lower degree of development of the Italian banking system by comparison with the rest of the euro area and even more with the British and American systems is connected with Italian banks' traditionally prudent lending policies and the relative unimportance of investment banking, which in hindsight proved to be much riskier than it might have seemed at first. The reasons for this greater prudence are not buried deep in the past. The drastic deterioration of borrowers' solvency in the mid-1990s, following the crisis that drove Italy out of the European Exchange Rate Mechanism in 1992 and brought a sharp recession the next year, had caused the bad loan ratio to leap to 12 per cent in 1996. Many banks that had been lax in borrower selection, in part for political reasons (Sapienza, 2004), were forcibly merged into sounder banks, mostly located in the Centre and North of Italy. The cleansing effect of this searing crisis for the banking system helped foster more careful screening by banks, with a greater capacity to monitor debtors and probably greater risk aversion (Bofondi and Gobbi, 2006). Today, despite the difficult cyclical phase, the bad debt ratio is no more than 5 per cent.

Prudence has been greatest in lending to households. For mortgage lending, the loan-to-value ratio is low by international standards. At the same time, Italian banks' lesser propensity for financial innovation discouraged such practices as mortgage equity withdrawals, which in some 
countries were the main driver of mortgage lending. Before 2007 the expansion of lending had sustained the demand for houses in the UK, Ireland, Spain and the United States, sparking a price boom. In Italy, the smaller size of the mortgage market attenuated the dependence of demand on credit and limited the impact on real estate prices. When the bubble burst the house price decline was not as sharp in Italy as elsewhere, and the effect on banks' balance sheets was correspondingly less severe.

The relatively modest amount of investment banking in Italy - linked with customers' lack of financial sophistication and the historic competitive disadvantage of Italian vis-à-vis British, American and the major German and French banks - was another factor making Italian banks less vulnerable to the crisis, thanks to their lesser exposure to opaque and risky financial assets. Moreover, some cases of bond defaults in previous years (Cirio, Parmalat, Argentine government paper) had made banks more cautious in marketing securities to customers, which attenuated the repercussions of the collapse in the financial markets on the portfolios of households and borrower firms. Finally, supervisory controls on securitizations prevented them from becoming a source of instability (Affinito and Tagliaferri, 2010; Albertazzi et al., 2011). Special purpose vehicles had no particular financial problems in Italy, and the conversion of asset-backed securities into potentially risky instruments like CDOs and CDOs-squared was negligible. This helped keep the overall leverage of the financial system relatively low. And if during the years of financial euphoria this obviously resulted in lower profitability, when the crisis came it limited the losses. Finally, Italian banks' low degree of internationalization ensured less exposure to the worst-hit financial markets. Prudent asset management and less aggressive use of leverage permitted greater prudence in funding as well. As we have seen, the share of banks' fund-raising that comes from retail customers is greater than in the other countries, while interbank liabilities - on which there was a run that brought the collapse of a good number of banks (Ivashina and Scharfstein, 2010; Gorton and Metrick, 2011) - are more limited. During the crisis the greater stability of banks' sources of 
funding eased the impact in Italy of the tensions in the international money markets, thanks in part to the supervisory authorities, who tightened controls on banks' liquidity as far back as 2007.

The milder impact of the crisis produced a more moderate deceleration of credit than in other countries. The large banks, with their greater dependence on the international interbank and bond markets, slowed their lending more sharply. In part the resulting slack was taken up by smaller banks, which exploited their direct relationships with customers at a time of uncertainty over borrowers' solvency. ${ }^{16}$ Credit growth - to both firms and households - is stronger now in Italy than in the euro-area countries as a group (Figures 14 and 15).

The repercussions of the financial crisis of 2007-09 on the productive economy could not fail to affect the Italian financial system, but Italian banks weathered the crisis better than those in most other countries. New problems were already looming, however.

\subsection{The sovereign debt crisis}

The massive government interventions in many countries to salvage the financial system in the 2007-09 crisis put a strain on Italian banks. The growing demand for public funds generated by budget deficits reduced the capacity of many nations to place their paper at sustainable interest rates. At first the debt crisis struck Greece, Ireland and Portugal, euro-area countries with large budget deficits. During that period, Italian banks' relative lack of internationalization appeared to be a strength: by comparison with German and French banks, they had much smaller investments in Greece, Ireland and Portugal (Table 6). ${ }^{17}$

During the summer of 2011 the sovereign debt crisis spread to Italy and threatened even France. Worried that Italian government securities make up some 40 per cent of Italian banks' bond

\footnotetext{
${ }^{16}$ Panetta and Signoretti (2010).

17 The data are from banks' consolidated accounts. For example, the exposure of Italian banks to Germany, by this gauge, includes the assets of Italian banks' German subsidiaries. In the same way, the exposure of French banks to Italy includes the assets of French banks' Italian subsidiaries.
} 
portfolio, the stock markets reacted negatively, with judgments out of line with the long-run performance of Italian banks. Home bias in portfolio composition is a feature of many other banking systems in countries with large public debts, such as Japan and Belgium. For Italian banks, holding the government securities of a euro-area country that are eligible as collateral for central bank refinancing has always been a factor of soundness. But the changed external framework has transformed what seemed to be a strength into a source of vulnerability, even though the pressures on the public debt are due to external causes and not to massive spending on bank bailouts as in, say, Ireland. ${ }^{18}$

The link between banks' balance sheets and the state of the public finances is much looser today than in the past. In the 1990s Italian government securities made up some 80 per cent of the securities held by Italian banks, compared with 40 per cent today. Italian banks held 50 per cent of all outstanding Italian government paper in the 1970s and 20 per cent in the 1990s, when the ratio of the debt to GDP had risen to the level it is still at, but today the banks hold only 14 per cent. Greater diversification of the bond portfolio (Committee on the Global Financial System, 2011) would reduce the risk of a diminution of asset liquidity and a rise in funding costs, associated with excessive exposure to securities that could come under pressure.

Any national banking system inevitably depends on the general performance of the country's economy. The consequences of the sovereign debt crisis are hard to foresee but they absolutely cannot be underestimated. A solution is essential not only to prevent the collapse of the financial system in some member countries but to ensure the very survival of the euro area. When the problem is resolved, Italian banks' traditional caution may well prove, once again, to have been a bulwark for the stability of our financial system.

\footnotetext{
18 As a result, on December 8th 2011 EBA published a formal recommendation on banks' recapitalisation needs involving among others also four Italian banks.
} 


\section{Conclusion}

For the banks, Italy's involvement in the sovereign debt crisis is an exogenous event. When the strains ease, the banking system will in any case be facing a series of problems that are difficult but within its power to solve. The banks will have to cut operating costs in proportion to gross income, as this ratio is high by international standards. At a time of considerable financial market uncertainty they will have to increase their net revenue from services. They must improve relations with customers, increasing contract transparency. And they must make additional improvements in their corporate governance.

The traditional business model of Italian banks differs sharply from the prevalent British and American models but also from that of other European countries. This model sheltered Italian banks from the explosive crisis of 2007-09, thanks to a series of factors: the large portion of funding consisting in deposits and bonds held by households, low leverage, an appreciably high level of profits by international standards, the central role of banks in the asset management industry either directly or through subsidiaries, the maintenance of private ownership, and lending rates that are at or below the prevalent euro-area rates for most products.

Twenty years ago Italian banks were largely state-owned, sometimes mismanaged. The largest southern banks were on the verge of a grave crisis. Their insolvency was overcome by government capital injections and the intervention of other banks. Privatizations and consolidation helped make the system more robust. Looking back on the progress made, there can be no doubt of Italian banks' ability to react successfully to the strains now affecting the euro area. 


\section{References}

Affinito, M., R. De Bonis and F. Farabullini (2006), "Strutture finanziarie e sistemi bancari: differenze e analogie tra i paesi europei", in M. De Cecco and G. Nardozzi, eds., Banche e finanza nel futuro: Europa, Stati Uniti, Asia, Bancaria editore.

Affinito, M., and E. Tagliaferri (2010), "Why Do (or Did) Banks Securitize Their Loans? Evidence From Italy", Banca d'Italia, Temi di discussione, no. 741, January.

Albertazzi, U., G. Eramo, L. Gambacorta and C. Salleo (2011), "Securitization is not that evil after all”, Banca d'Italia, Temi di discussione, no. 796, February.

Alessandrini, P., A. Presbitero and A. Zazzaro (2009), "Banks, distances and firms' financing constraints", Review of Finance, 13, 261-284.

Allen, F., and D. Gale (2000), Comparing Financial Systems, Cambridge University Press.

Ayadi R., D. T. Llewellyn, R. H. Schmidt., E. ArbaK and W. P. De Green, (2010), Investigating Diversity in the Banking Sector in Europe. Key Developments, Performance and Role of Cooperative Banks, Centre for European Policy Studies.

Angelini, P., and N. Cetorelli (2003), "The Effects of Regulatory Reform on Competition in the Banking Industry", Journal of Money, Credit and Banking, 35, 663-84.

AUTORITÀ GARANTE DELLA CONCORRENZA E DEL MERCATO (2010), Relazione annuale.

BofONDI, M., and G. GoBBI (2006), "Informational barriers to entry into credit markets", Review of Finance, 10, 39-63.

Caiazza, S., A.F. Pozzolo and G. Trovato (2011), "Are Domestic and Cross-Border M\&As Different? Cross-Country Evidence From the Banking Sector", available at SSRN: http://ssrn.com/abstract=1443919

Cappelletti, G., A. De Socio, G. Guazzarotti G. and E. Mallucci (2011), "The impact of the financial crisis on interbank funding: evidence from Italian balance sheet data", Banca d'Italia, Quaderni di economia and finanza, no. 95, July.

CARosio, G. (2011), Indagine conoscitiva sui mercati degli strumenti finanziari, Testimony to the Finance Committee of the Chamber of Deputies, Rome, 4 May.

Cau, G., R. De Bonis, F. Farabullini and A. Salvio (2004), "Efficienza allocativa: ci sono differenze tra banche popolari e banche società per azioni?", in R. de Bruyn and G. Ferri (eds.), Le banche popolari nel localismo dell'economia italiana, Quaderni dell'Associazione delle banche popolari, no. 3/4.

Cetorelli, N., and P. Strahan (2006), "Finance as a Barrier to Entry: Bank Competition and Industry Structure in Local U.S. Markets", Journal of Finance, LXI. 
COMmitTeE ON THE Global FinANCIAL System (2011), "The impact of sovereign credit risk on bank funding conditions", CGFS no. 43, July.

De Bonis, R., and A. FERRANDO (2000), "The Italian banking structure in the nineties: testing the multimarket contact hypothesis", Economic Notes, July, 215-241

DE Bonis, R., and A. Pozzolo (2012) (eds.), The Financial Systems of Industrial Countries. Evidence from Financial Accounts, Springer.

DemirgüÇ-Kunt, A., and R. Levine (2001), Financial Structure and Economic Growth, The MIT Press.

Enriques L., G. Siciliano and M. Gentile (2011), "La Borsa italiana dal secondo dopoguerra alla fine del Novecento. Fatti e interpretazioni”, paper presented at conference of Società Italiana di Statistica (SIS), Bologna, 8-10 June.

European Central Bank (2010), Financial Stability Review. Special Features: Basel III, December.

EuROPEAN COMMISSION (2006), Interim Report II. Current Accounts and Related Services. Sector Inquiry on Retail Banking, July.

FocARELli, D., and A.F. Pozzolo (2001), "The Patterns of Cross-Border Bank Mergers and Shareholdings in the OECD Countries", Journal of Banking and Finance, 25, 23052337.

Gerschenkron, A. (1962), Economic Backwardness in Historical Perspective, Harvard University Press.

GoBBi, G. (2008), "Indagine conoscitiva sulle determinanti della dinamica del sistema dei prezzi e delle tariffe, sull'attività dei pubblici poteri e sulle ricadute sui cittadini consumatori|", Senato della Repubblica, Rome, 11 March.

Gorton, G., and A. METRICK (2011), "Securitized banking and the run on repo", Journal of Financial Economics.

Guiso, L., P. SAPIEnZA and L. Zingales (2004), "The Role of Social Capital in Financial Develpoment”, American Economic Review, vol. 94 (3), 526-556.

INFANTE, L., and P. ROSSI (2009), "L'attività retail delle banche estere in Italia: effetti sull'offerta di credito alle famiglie e alle imprese", Banca d'Italia, Temi di discussione, no. 714, June.

INFANTE, L., and M. PiAZZA (2011), "Do political connections pay off? Some evidences from the Italian credit market", Banca d'Italia, mimeo.

International MONETARy Fund (2011), Italy. Staff Report for the 2011 Article IV Consultation, June. 
IVAShinA, V., and D. SCHARFSTEIN (2010), "Bank lending during the financial crisis of 2008”, Journal of Financial Economics, 97, 319-338.

La Porta, R., F. Lopez de Silanes, A. Shleifer and R W. Vishny (1997), "Legal Determinants of External Finance”, Journal of Finance, Vol. 52(3), pp. 1131-50.

LEVINE, R., and S. ZeRvos (1998), "Stock Markets, Banks, and Economic Growth", American Economic Review, vol. 88(3), 537-558.

MEHRAn, H., A. MorRISON and J. SHAPIRO (2011), Corporate Governance and Banks: What Have We Learned from the Financial Crisis? Federal Reserve Bank of New York, Staff Report no. 502, June.

Messori, M., R. TAMBORINI and A. ZAZZARo (2003) (eds.), Il sistema bancario italiano. Le occasioni degli anni Novanta e le sfide dell'euro, Carocci.

MirRA, L., and A. F. Pozzolo (2011), "I prestiti bancari alle imprese in Italia: gli andamenti di lungo periodo", mimeo.

Nuzzo, G., and E. Oliverio (2011), "Banche locali e banche del Centro Nord nel Mezzogiorno: evoluzione temporale e confronto con altre aree in ritardo di sviluppo", Banca d'Italia, mimeo.

Paiella, M., and A.F. Pozzolo (2007), "Choosing between Fixed and Adjustable Rate Mortgages", in S. Agarwal and B. Ambrose (eds.), Household Credit Usage Personal Debt and Mortgages, Palgrave, MacMillan.

PANETTA, F. (2004) (ed.), Il sistema bancario italiano negli anni novanta: gli effetti di una trasformazione, Il Mulino, Bologna.

PANeTtA, F., and F. M. Signoretti (2010), "Domanda e offerta di credito in Italia durante la crisi finanziaria", Banca d'Italia, Quaderni di economia e finanza, no. 63, April.

Panetta, F., T. Faeh, G. Grande, C. Ho, M. King, A, Levy, F. M. Signoretti, M. Taboga and A. ZAGHINI (2010), "An assessment of financial sector rescue programmes", Banca d'Italia, Quaderni di economia e finanza, no. 47, July.

PiAZZA, M. and M. STACCHINI (2007), "What's risk got to do with it? An analysis of interest rates in the Italian consumer credit market", Banca d'Italia, mimeo.

Piscitello, L., and A.F. Pozzolo (2006), "Tendenze di internazionalizzazione del sistema bancario italiano nel contesto europeo", in F. Onida (ed.), Internazionalizzazione e servizi finanziari per le imprese, Bancaria Editore, Rome, 2006.

RAJAN, R.G., and L. Zingales (2003), "The Great Reversals: The Politics of Financial Development in the 20th Century", Journal of Financial Economics, vol. 69(1), 550 . 
SAPIENZA, P. (2004), "The effects of government ownership on bank lending", Journal of Financial Economics, 72, 357-384.

SILIPO, D.B. (2009) (ed.), The Banks and the Italian Economy, Physica Verlag.

STACCHINI, M., and G. CAU (2010), "The certification role of bank directors on corporate boards", MoFiR Working paper no. 46, November.

TARAntola, A. M. (2011), "La riforma delle banche popolari”, Testimony before the Finance and Treasury Committee of the Senate, Rome, 22 June. 


\section{Appendix}

The Italian banking system:

Facts and interpretations 


\begin{tabular}{|c|c|c|c|c|c|}
\hline & Euro area & Germany & Spain & France & Italy \\
\hline Total assets & 3.50 & 3.32 & 3.27 & 4.02 & 2.45 \\
\hline Loans to households & 0.56 & 0.57 & 0.83 & 0.52 & 0.38 \\
\hline of wihich: for house pur chase & 0.40 & 0.39 & 0.63 & 0.40 & 0.23 \\
\hline consumer credit & 0.07 & 0.07 & 0.08 & 0.08 & 0.04 \\
\hline other & 0.09 & 0.11 & 0.12 & 0.04 & 0.11 \\
\hline Loans to fir ms & 0.51 & 0.36 & 0.86 & 0.43 & 0.57 \\
\hline Deposits & 2.19 & 2.07 & 2.39 & 2.29 & 1.47 \\
\hline $\begin{array}{l}\text { memo: Total bank assets/financial } \\
\text { assets of entir e economy }\end{array}$ & 0.32 & 0.31 & 0.29 & 0.29 & \\
\hline
\end{tabular}


The Italian banking system: Facts and interpretations

\begin{tabular}{|lrrrr|}
\hline \multicolumn{4}{|c|}{ TABLE 2. Structure of the banking system in the large euro-area } \\
countries, end-2009 \\
\hline & Germany & Spain & France & Italy \\
\hline Herfindahl index. assets & 206 & 507 & 605 & 353 \\
\hline Market shar e of top 5 banks. \% & 25.0 & 43.3 & 47.2 & 34.0 \\
Average size ( $€$ mn) & 3.811 .1 & 9.753 .6 & 10.049 .8 & 4.609 .2 \\
\hline Branches per 100.000 r esidents & 48.1 & 96.7 & 59.7 & 56.5 \\
Branches per bank & 20.2 & 126.2 & 54.0 & 42.5 \\
Employees per branch & 17.3 & 6.0 & 12.4 & 9.9 \\
Share of total work for ce. \% & 1.7 & 1.2 & 1.8 & 1.4 \\
\hline Source: ECB - EU Banking Str uctures (2010). & & & & \\
\hline
\end{tabular}




\begin{tabular}{|c|c|c|c|c|c|}
\hline \multicolumn{6}{|c|}{$\begin{array}{c}\text { TABLE 3a. Composition of banks' balance sheets in the large } \\
\text { euro-area countries: Assets } \\
\text { (ratio of main items to total assets, end-2010) }\end{array}$} \\
\hline & Euro area & Germany & Spain & France & Italy \\
\hline Loans & 0.64 & 0.65 & 0.69 & 0.60 & 0.66 \\
\hline \multicolumn{6}{|l|}{ Loans } \\
\hline to households & 0.17 & 0.17 & 0.25 & 0.13 & 0.16 \\
\hline \multicolumn{6}{|l|}{ of which: } \\
\hline for house pur chase* & 0.12 & 0.12 & 0.19 & 0.10 & 0.09 \\
\hline consumer cr edit* & 0.02 & 0.02 & 0.02 & 0.02 & 0.02 \\
\hline other* & 0.03 & 0.03 & 0.03 & 0.01 & 0.05 \\
\hline Loans to fir ms & 0.15 & 0.11 & 0.26 & 0.11 & 0.23 \\
\hline Loans to monetar y financial institutions & 0.23 & 0.26 & 0.12 & 0.28 & 0.13 \\
\hline Non-equity securities & 0.23 & 0.26 & 0.12 & 0.28 & 0.13 \\
\hline \multicolumn{6}{|l|}{ of which: } \\
\hline \multicolumn{6}{|l|}{ issued by non-r esidents } \\
\hline issued by gover nments** & 0.05 & 0.04 & 0.05 & 0.04 & 0.07 \\
\hline issued by banks** & 0.06 & 0.08 & 0.02 & 0.06 & 0.06 \\
\hline Shares and other equity & 0.05 & 0.04 & 0.05 & 0.07 & 0.06 \\
\hline Other assets & 0.12 & 0.14 & 0.08 & 0.17 & 0.10 \\
\hline \multicolumn{6}{|l|}{$\begin{array}{l}\text { Source: ESCB har monized statistics. } \\
\text { **Euro-area resident counterpar ties. } \\
\text { **Euro-area residents. Rounding may ca }\end{array}$} \\
\hline
\end{tabular}




\begin{tabular}{|c|c|c|c|c|c|}
\hline & Euro area & Germany & Spain & France & Italy \\
\hline Deposits & 0.64 & 0.62 & 0.72 & 0.56 & 0.60 \\
\hline \multicolumn{6}{|l|}{ of which: } \\
\hline of banks & 0.26 & 0.24 & 0.18 & 0.32 & 0.21 \\
\hline of residents* & 0.32 & 36 & 0.50 & 0.21 & 0.37 \\
\hline current accounts** & 0.12 & 0.13 & 0.15 & 0.07 & 0.20 \\
\hline with agreed maturity** & 0.14 & 0.14 & 0.33 & 0.08 & 0.06 \\
\hline redeemable at notice** & 0.06 & 0.08 & 0.00 & 0.07 & 07 \\
\hline Debt securities issued & 0.15 & 0.17 & 0.12 & 0.14 & 0.21 \\
\hline Capital and $r$ eserves & 0.06 & 0.05 & 0.08 & 0.06 & 0.09 \\
\hline Other liabilities*** & 0.15 & 0.16 & 0.07 & 0.23 & 0.10 \\
\hline
\end{tabular}

\begin{tabular}{|lrrrrr|}
\hline $\begin{array}{r}\text { TABLE 4. Internationalization of the banking system in the large } \\
\text { euro-area countries, end-2009 (percentages) }\end{array}$ \\
\hline \multicolumn{4}{|c}{$\begin{array}{l}\text { Germany } \\
\text { Spain }\end{array}$} & France & Italy \\
\hline Assets & 28.5 & 12.1 & 28.7 & 10.0 \\
\hline of which: in EU & 21.1 & 8.9 & 20.4 & 8.7 \\
\hline Prestiti & 24.9 & 8.2 & 23.8 & 7.4 \\
\hline Loans & 17.6 & 21.6 & 28.6 & 20.4 \\
\hline of which: in EU & 11.8 & 18.8 & 17.0 & 17.3 \\
\hline Interbank deposits & 34.9 & 40.4 & 39.7 & 49.1 \\
\hline of which: in EU & 26.0 & 35.4 & 22.3 & 44.4 \\
\hline Source: ECB - EU Banking Str uctures (2009). & & & & \\
\hline
\end{tabular}




\begin{tabular}{|c|c|c|c|c|}
\hline & Germany & Spain & France & Italy \\
\hline \multicolumn{5}{|c|}{ Foreign banks' market share } \\
\hline \multicolumn{5}{|c|}{ Branches* } \\
\hline Number & 5.2 & 24.6 & 12.8 & 10.0 \\
\hline Assets & 2.5 & 6.5 & 2.0 & 6.4 \\
\hline of which: of EU banks & 2.1 & 6.4 & 18 & 62 \\
\hline \multicolumn{5}{|l|}{ Subsidiaries } \\
\hline Number & 2.5 & 12.2 & 17.0 & 2.7 \\
\hline Assets & 8.3 & 3.6 & 8.7 & 7.0 \\
\hline of which: of EU banks & 7.6 & 3.3 & 8.0 & 6.6 \\
\hline \multicolumn{5}{|c|}{ Banks' net external position } \\
\hline as $\%$ of GDP & 18.7 & -48.9 & -11.1 & -21.2 \\
\hline as $\%$ of total assets & 6.1 & -15.0 & -3.0 & -8.7 \\
\hline
\end{tabular}


The Italian banking system: Facts and interpretations

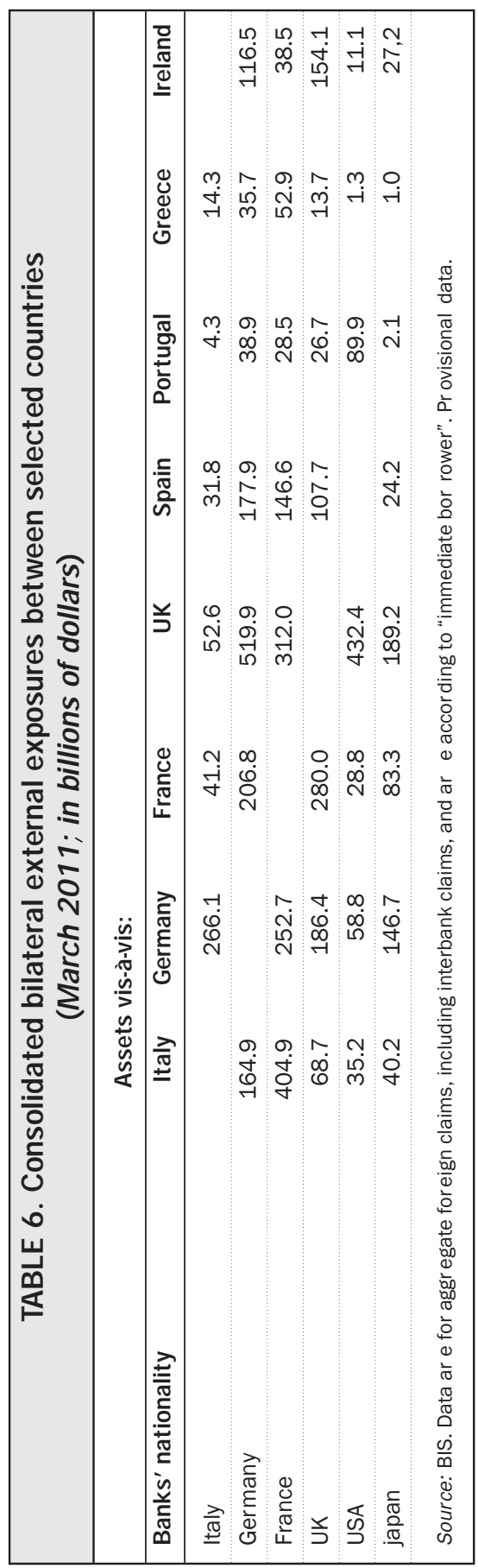




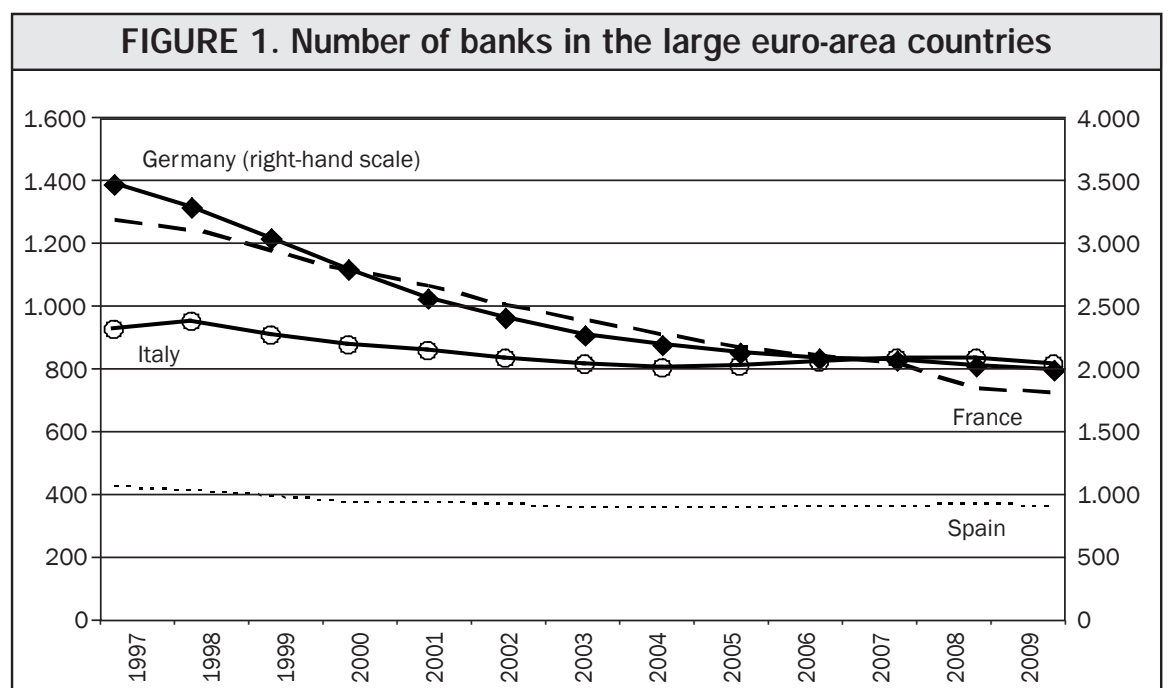

Source: ECB - EU banking str uctures, various years

FIGURE 2. Number of bank branches in the large euro-area countries

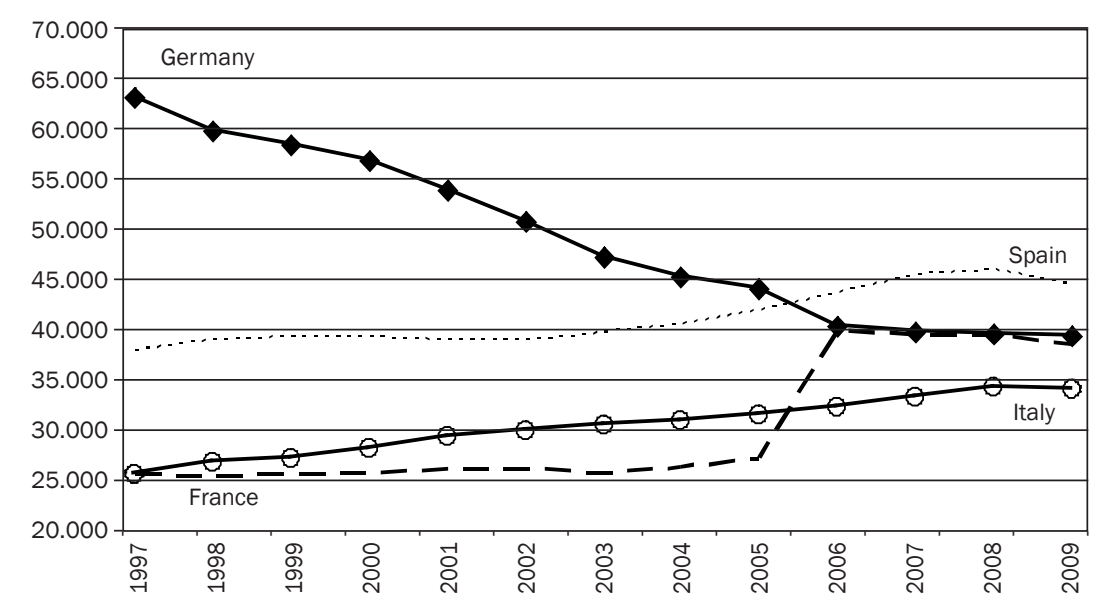

Source: ECB - EU banking str uctures, various years. 

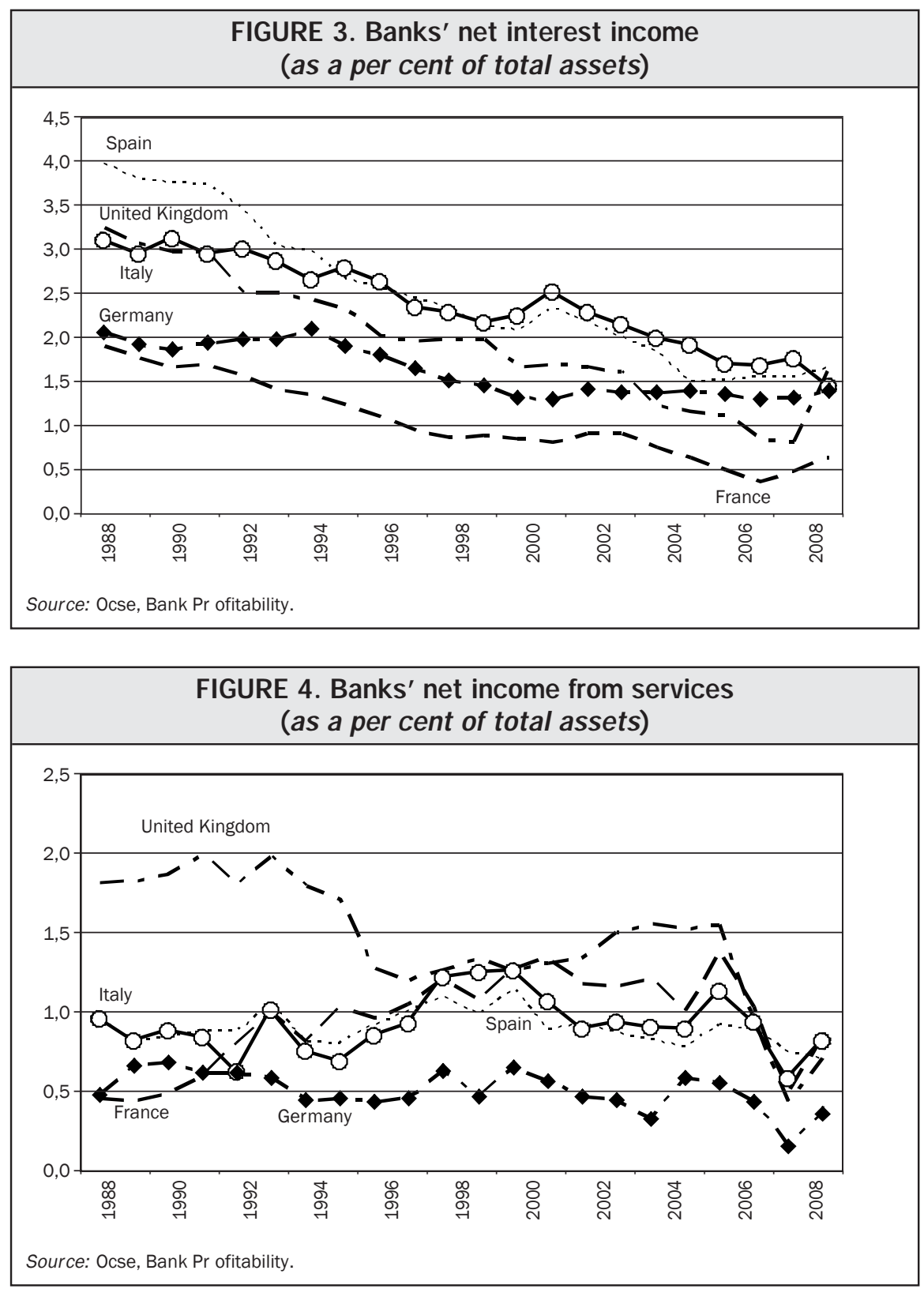

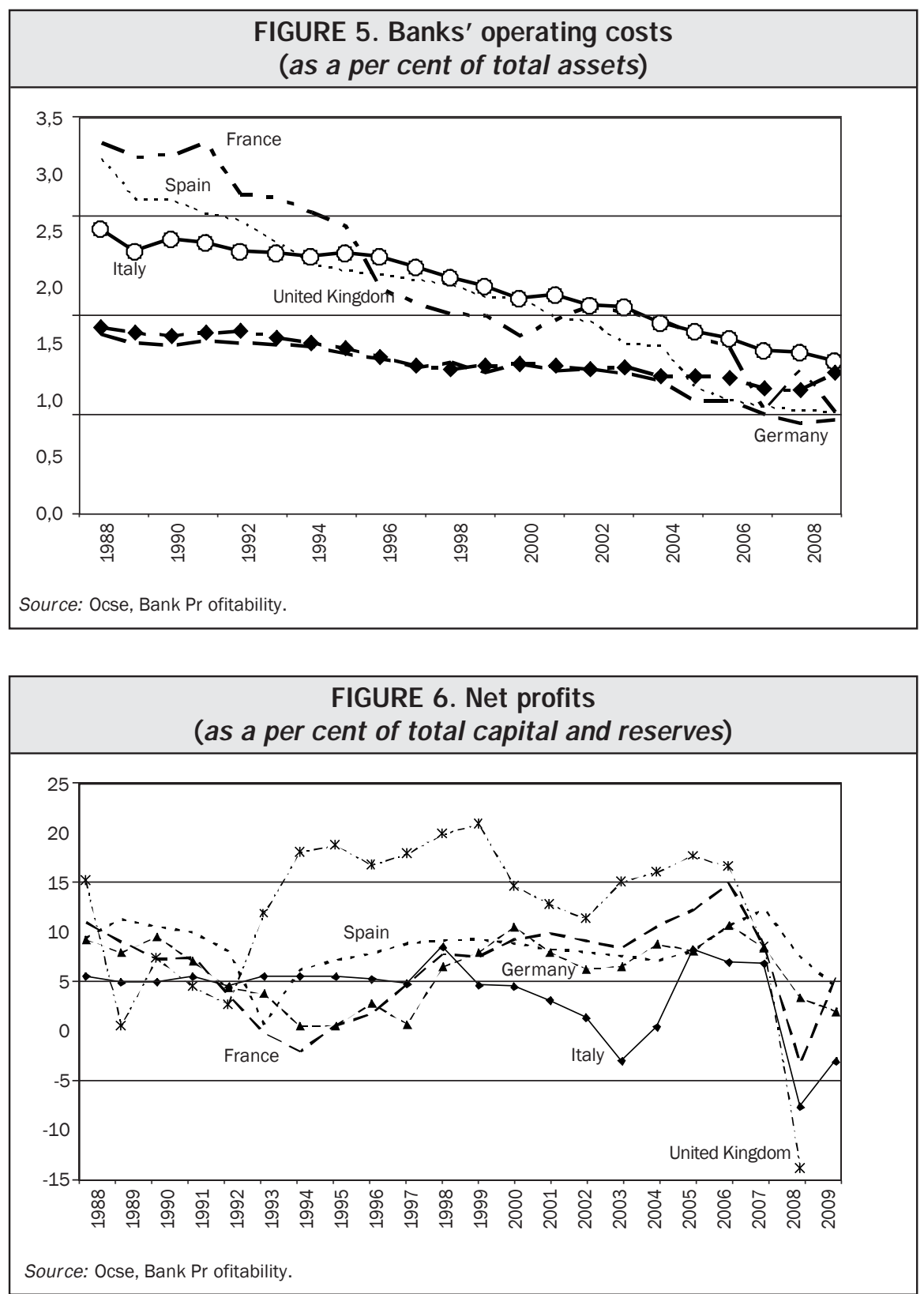

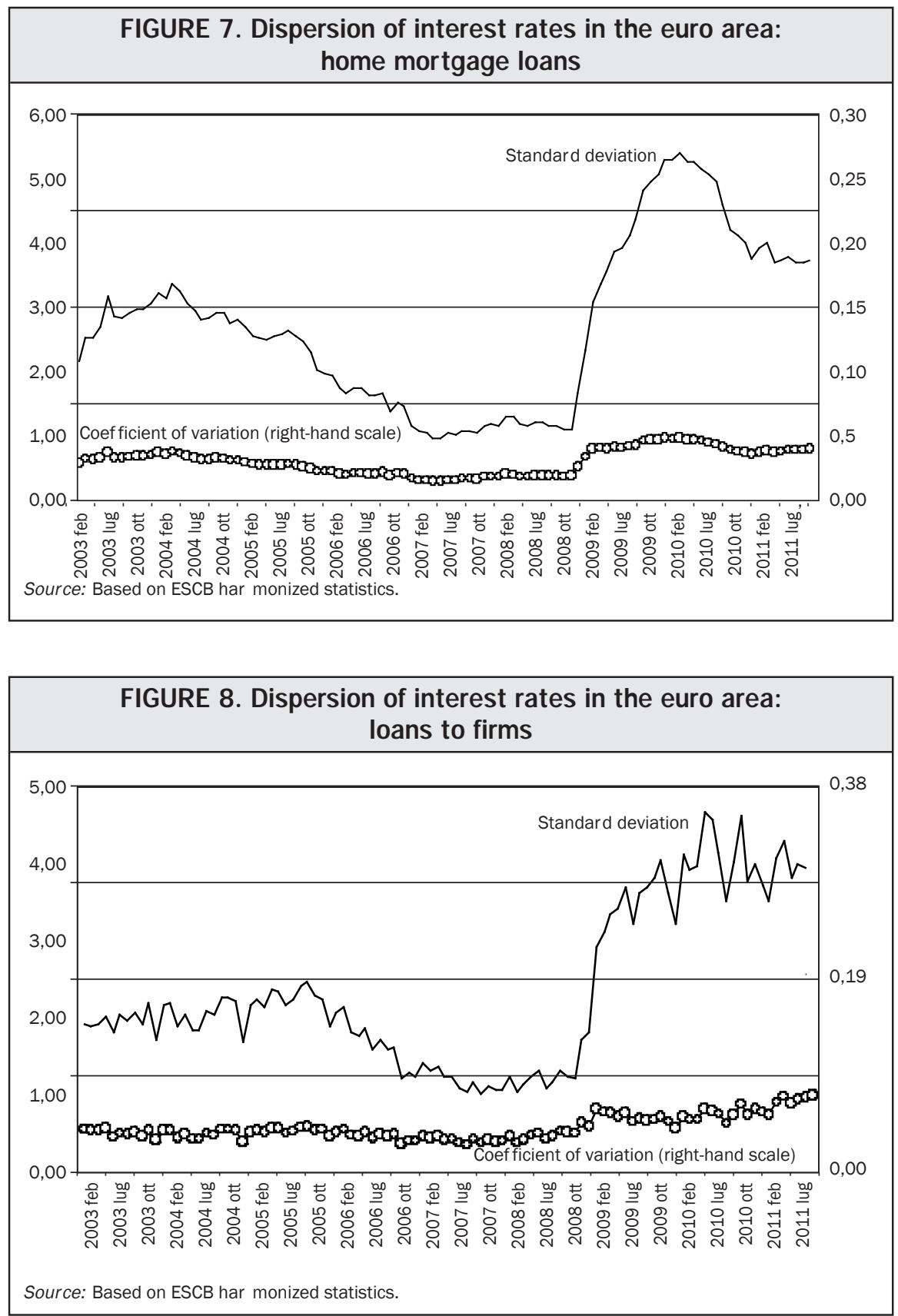

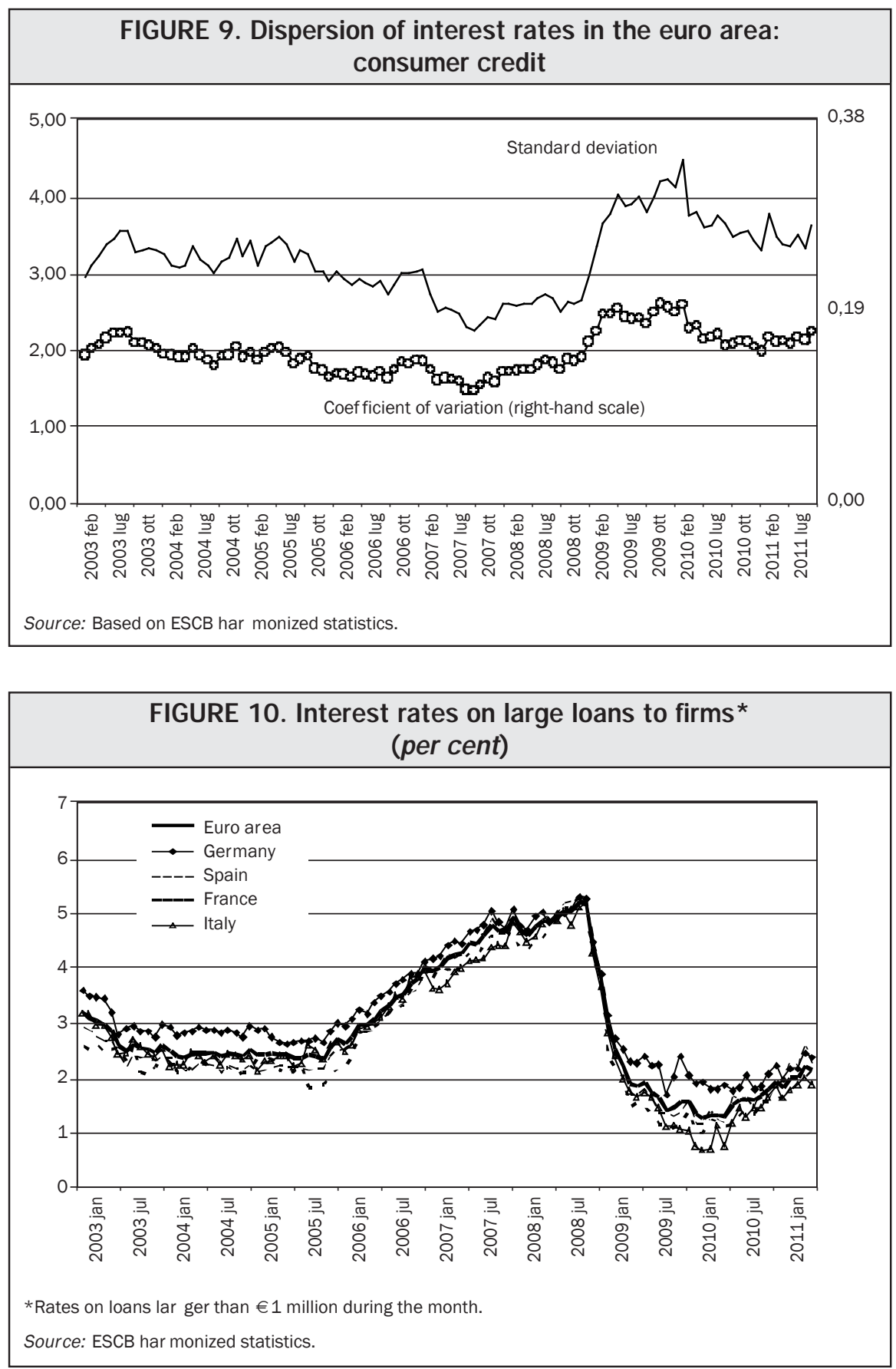

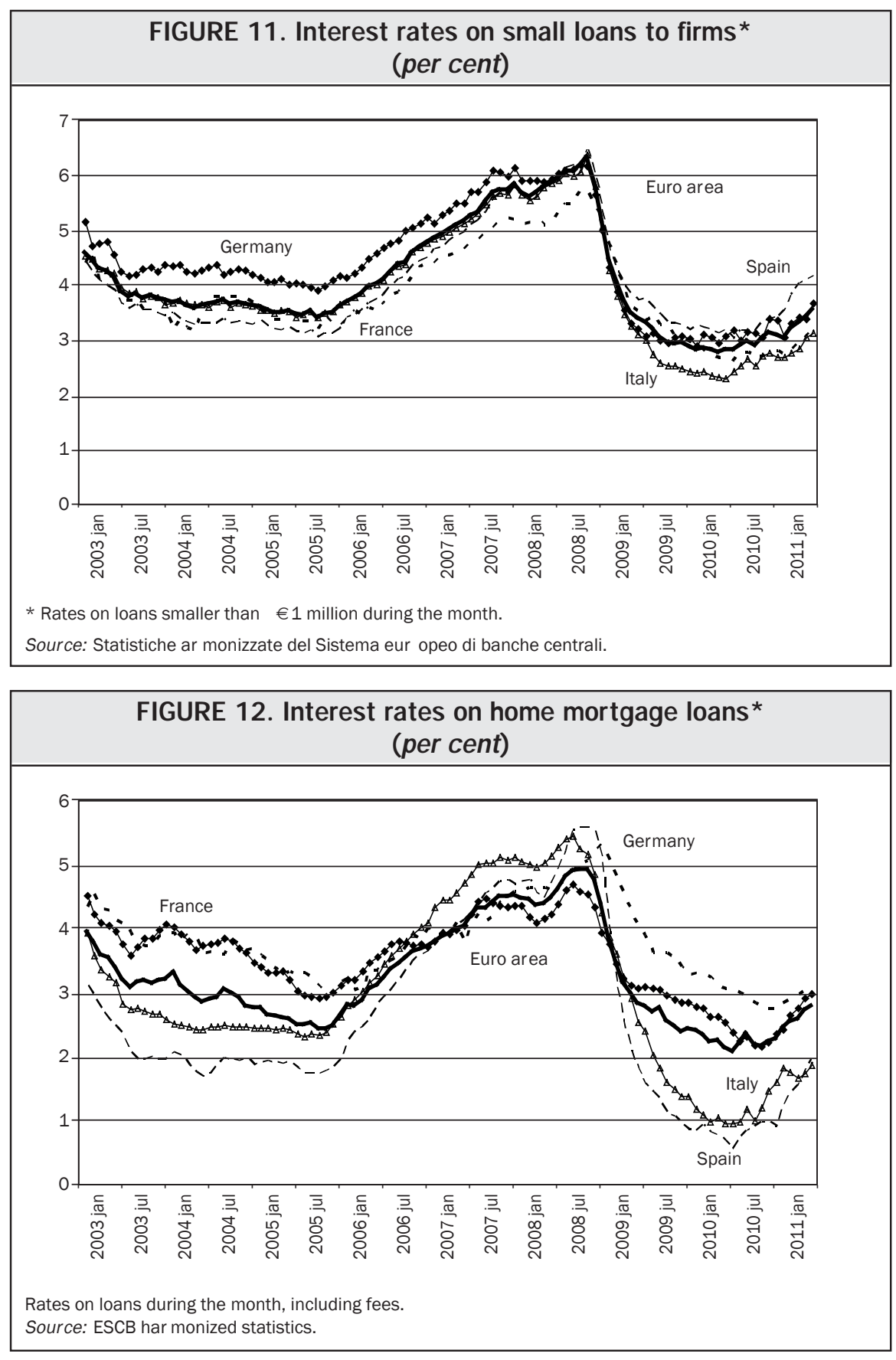

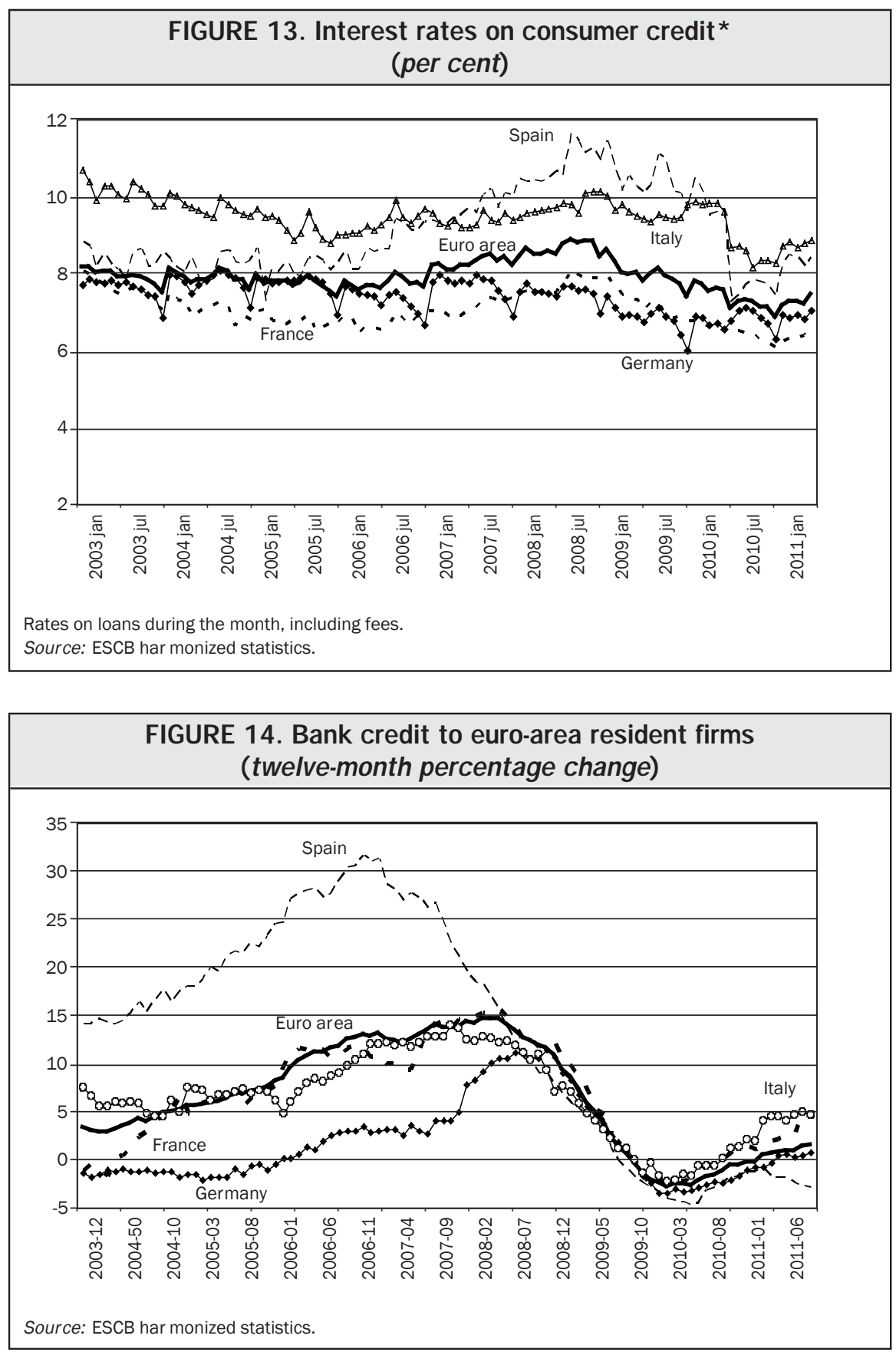


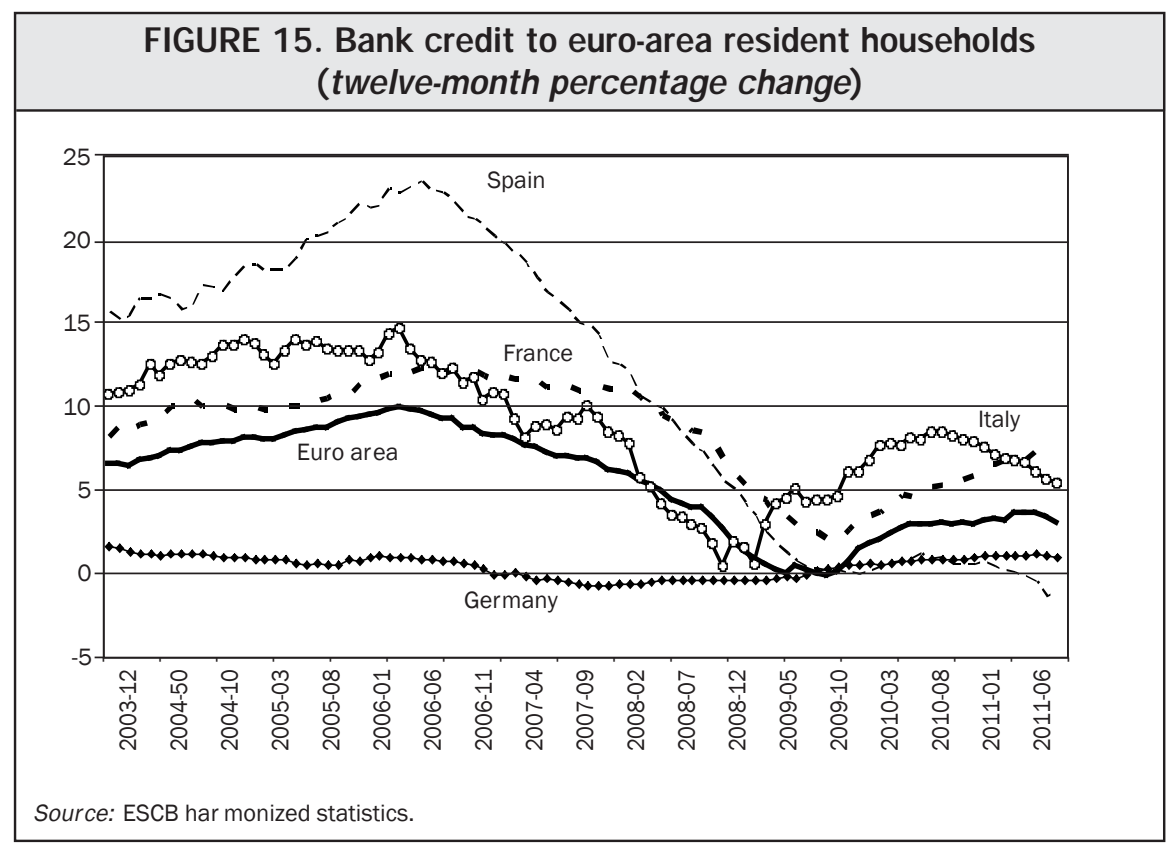

